\title{
Reducing of process model uncertainty towards smart machining systems
}

\author{
Zmniejszanie niepewności modelu procesu \\ w inteligentnych systemach obróbki skrawaniem
}

\section{NEVEN TRAJCHEVSKI MIKOLAJ KUZINOVSKI MITE TOMOV PIOTR CICHOSZ*}

This paper presents an approach of empirical modeling of cutting process physical phenomena with measurement uncertainty parameters accompanied to the model exponents/ /coefficients. The approach is presented trough an example of creating a power mathematical model for average cutting temperature in turning with details about the uncertainty contributions from different experimental plans. The approach is proposed to be implemented as usual practice during empirical modeling, in order the resulting models to fit with the needs of the smart machining systems and the needs of interoperability between researchers.

KEYWORDS: uncertainty, empirical modeling, smart machining system, cutting temperature, cutting forces

W pracy przedstawiono propozycję modelowania empirycznego zjawisk fizycznych w skrawaniu z uwzględnieniem parametrów niepewności pomiarowej oraz modelowych współczynników. Propozycję tę zaprezentowano na przykładzie modelu matematycznego temperatury skrawania, z podaniem danych dotyczących składowej niepewności z różnych planów eksperymentalnych. Postuluje się wdrożenie tego podejścia podczas modelowania empirycznego, tak aby otrzymane modele odpowiadały potrzebom inteligentnych systemów obróbki skrawaniem oraz potrzebom interoperacyjności między naukowcami.

SŁOWA KLUCZOWE: niepewność, modelowanie empiryczne, inteligentny system obróbki, temperatura skrawania, siły skrawania

The evolution of machining followed by the development of the computer aided design (CAD)/computer aided manufacturing (CAM)/computer aided engineering (CAE) systems and process monitoring and control modules brought to us the possibilities of faster machining with increased accuracy and precision. This is the result of implementing a number of new hardware and software tools from various manufacturers. However, if we compare it to the advances in other areas in the industries, we can face significant drawback as a result of the lack of standards in the area of interoperability of the vast number of modules, controllers, and software tools. This means that the advances achieved within some elements or by some manufacturers cannot be used widely due to the closed hardware and software components, as well as the copyrights. The current focus in the development in the field is the creation of smart machining systems (SMS) [2-4]. As defined in [2], SMS is a machine that knows its capabilities to come up with the most efficient way of producing a correct

\footnotetext{
* Ass. prof. NevenTrajchevski (neven trajchevski@gmail.com) - Goce Delchev University, Macedonia; prof. Mikolaj Kuzinovski (mikolaj.kuzinovski@mf.edu.mk), assoc. prof. Mite Tomov (mite.tomov@mf.edu.mk) - Faculty of Mechanical Engineering, Cyril and Methodius University in Skopje, Macedonia; prof. dr. hab. inż. Piotr Cichosz (piotr.cichosz@pwr. edu.pl) - Department of Machine Tools and Mechanical Engineering Technologies, Faculty of Mechanical Engineering. Wroclaw University of Technology, Poland
}

\author{
DOI: https://doi.org/10.17814/mechanik.2018.10.150
}

part in the first time, every time and will check and monitor itself using the data to help close the gap between the designer, manufacturing engineer, and the shop floor. SMS are envisioned to overcome the drawbacks that we stated previously and to provide future development based on an open architecture system.

In Fig. 1 is shown an example of SMS architecture. One focus of this paper is to propose what the approach of the creators of the knowledge base should be (which the Supervisory System is dependent upon), so that the research results would be used in the SMS and so that the scientific and the engineering practices would be interoperable.

Our practice says that considering and accounting for the measurement errors and the empirical model uncertainty is as much important as the modeling itself and it can be the key element of finding common base between different researches, and it is essential to the SMS knowledge base. Otherwise the empirical modeling results most probably are being used by wrong or different interpretation.

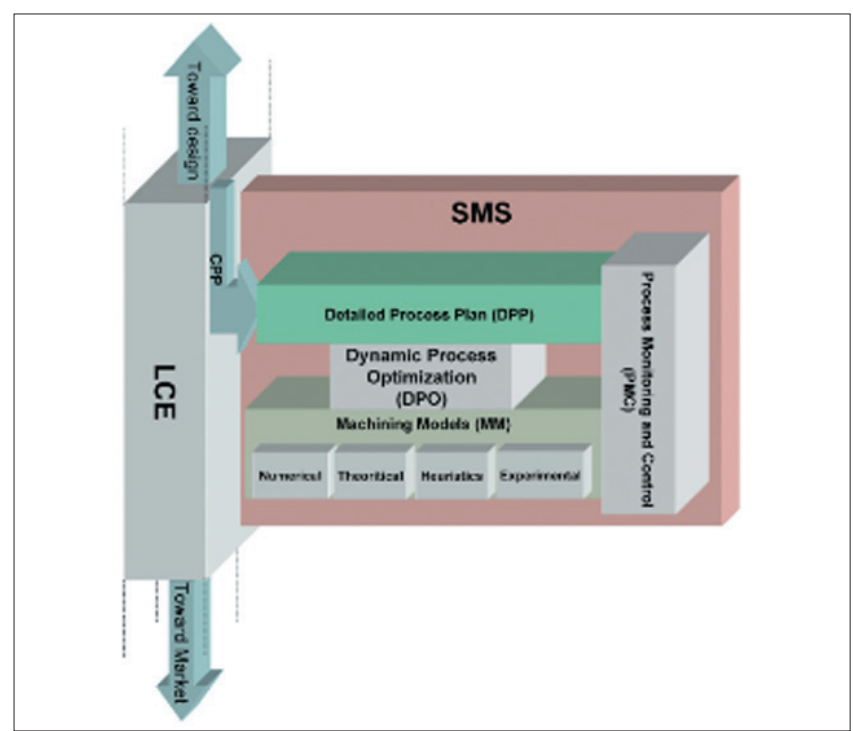

Fig. 1. Smart machining system architecture [3]

\section{Empirical modeling and uncertainty towards SMS}

The mutual need of the machine and the engineers, besides knowing the mathematical relations between the physical phenomena that occur and the machining process itself, is the need of knowing the limits within it are applicable and reliable. The smart knowledge-based adaptive optimization systems should select information, upon which they will make a decision from the list of numerical, theoretical, heuristics or empirical models. The more reliable these models will be the less need for selfmonitoring will be necessary. Herein we can try to identify the different approaches of the empirical modeling and their value regarding the interoperability and reliability. 
The most common approach for empirical modeling is by measuring the physical phenomena of interest in the experimental hyperspace and then fitting the mathematical model based on these data.

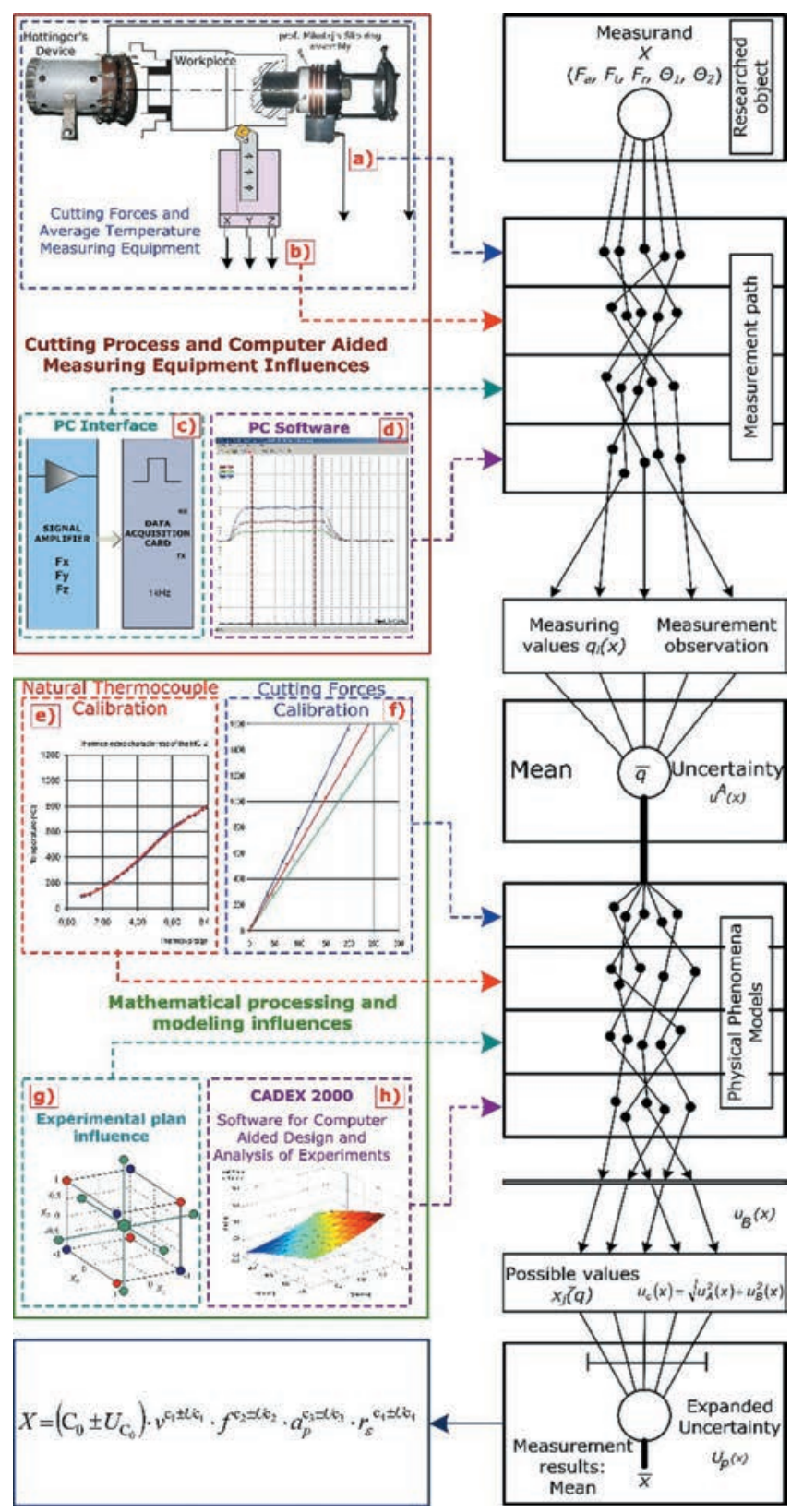

Fig. 2. Influence of the error sources on the mathematical modeling

The discrepancy between experimental results from different researches is mostly a result of different metrological practices $[1,5]$. And all these can be associated to how the researcher is approaching the experiment and the experimental errors. In our opinion the differences in views based on published papers can be summarized as follows: - The empirical errors are minimized. In this approach the empirical modeling is done by assuming that the cutting process parameters are the ones which are programmed, and the measured values are considered as accurate. The regression coefficient is usually generalized as the measure of the error of the experimental modeling when the adequacy test of the fitted model is positive.

- The empirical errors are considered. In this approach the measurement uncertainty of the measuring equipment is considered. The drawback is that the uncertainty of the cutting process itself is not considered.
- The measurement uncertainty of the measurement equipment and the cutting process itself is considered. Although with this approach all the sources of the measurement uncertainty are considered and identified, the uncertainty is associated to the single measurement of the experimental plan and there is a lack of information on how that influences the accuracy of the mathematical models or the determined mathematical model coefficients.

- A comprehensive approach of identifying and presenting of the empirical errors. Our view and proposal is to consider the measurement uncertainty of the measuring equipment, the measurement uncertainty of the cutting process itself, the uncertainty as a result of the mathematical modeling (of the experimental plan), the representation of the measurement uncertainty to be done within the final result of the experimental research - the mathematical model coefficients. In Fig. 2 such approach is presented, where all the sources of errors are accounted for in the uncertainty parameters, which are added to the final mathematical model coefficients.

Furthermore, we will describe one research example and the experimental research stand showed in Fig. 2, which is intended for the research of the forces and the average cutting temperature during turning. In the figure we can note that during a single measurement of one of these quantities, it is considering the influence of the measuring equipment $(a, b)$, the influence of the personal computer interface and software $(c, d)$, the influence of the calibration $(e, f)$ and further when modeling the mathematical model by using full factorial experimental plan by the design of experiment methodology (DOE) the influence of the selected mathematical modeling procedure or plan $(g, h)$ is considered.

The research was performed and the results including the proposed approach are the subject of detailed description and publishing [6]. However, for this paper it is of interest to present the final results and the significant influence of the selected experimental plan as one of the previously described neglected source of error.

\section{Experimental research}

Within the experimental measurements and investigation in [7] there have been recorded results about the relative expanded uncertainty of single measurement of the cutting force component and the average cutting temperature. Even if we compare them with other authors' results and by applying the best measurement practices, we can agree that the value of the relative expanded uncertainty is less than $10 \%$, in our experiments for the cutting force measurement it was $8 \%$, and for the average cutting temperature $2 \%$. We believe that such values are not comprehensive enough to be taken as a measure of the error of the experimental research. Therefore, we use such distributed values of single measurements within the DOE experimental plan, which can have 20 single measurements for four factor full factorial design $\left(2^{4}+4\right)$ or 11 single measurements for the replica $\left(2^{4-1}+3\right)$, further to combine them and propagate such distributed single measurements values by the DOE regression matrix in order to find the exponents of the desired mathematical model and their uncertainties.

The experiment was performed under the following conditions: the workpiece material carbon steel, EN C55; cutting tool holder Kennametal IK.KSZNR-064 25×25; cutting insert Hertel SNGN 120704 mixed ceramics $\mathrm{MC} 2\left(\mathrm{Al}_{2} \mathrm{O}_{3}\right.$ $+\mathrm{TiC})$; cutting tool geometry $\kappa_{\mathrm{r}}=85^{\circ}, \kappa_{\mathrm{r} 1}=5^{\circ}, \gamma_{0}=-6^{\circ}$, 
$\alpha_{0}=6^{\circ}, \lambda_{\mathrm{S}}=-6^{\circ}$, where the mathematical model is showed by (1), and where $\Theta$ is the average cutting temperature, $v$ is the cutting speed, $f$ is the feed rate, $a_{p}$ is the depth of cut and $r_{\varepsilon}$ is the cutting tool nose radius, $c_{i}$ are the mathematical model coefficients (exponents), while the cutting parameters are varied between two levels each, as presented in table I.

TABLE I. DOE factors level values

\begin{tabular}{|c|c|c|}
\hline Cutting parameters & Level & Values \\
\hline \multirow{2}{*}{$v_{\mathrm{c}}, \mathrm{m} / \mathrm{min}$} & low & 46 \\
\cline { 2 - 3 } & high & 92 \\
\hline \multirow{2}{*}{$f, \mathrm{~mm} / \mathrm{rev}$} & low & 0.16 \\
\cline { 2 - 3 } & high & 0.315 \\
\hline \multirow{2}{*}{$a_{\mathrm{p}}, \mathrm{mm} / \mathrm{rev}$} & low & 0.5 \\
\cline { 2 - 3 } & high & 1 \\
\hline \multirow{2}{*}{$r_{\varepsilon}, \mathrm{mm} / \mathrm{rev}$} & low & 0.4 \\
\cline { 2 - 3 } & high & 1.2 \\
\hline
\end{tabular}

$$
\Theta=c_{0} \cdot v_{\mathrm{c}}^{c_{1}} \cdot f^{c_{2}} \cdot a_{\mathrm{p}}^{c_{3}} \cdot r_{\varepsilon}^{c_{3}}
$$

The results of the investigation are presented in table II, where we can see the values of the fitted coefficients of the mathematical model and every one of these coefficients is accompanied by the uncertainty parameter of the expanded measurement uncertainty, which is propagated upon the same equation upon which the coefficient is calculated following the ISOGuide to the expression of uncertainty in measurement.

TABLE II. Mathematical model coefficients and their uncertainty for different experimental plans

\begin{tabular}{|c|c|c|c|c|c|c|}
\hline \multirow{2}{*}{$\begin{array}{c}\text { Coefficient } \\
\text { (exponent) }\end{array}$} & \multicolumn{2}{|c|}{ Full factorial experimental plan } & \multicolumn{3}{c|}{ Half-replica } \\
\cline { 2 - 7 } & Value & $\begin{array}{c}\text { Expanded } \\
\text { uncertainty } \\
U c_{\mathrm{i}}\left(k_{\mathrm{p}}=2\right)\end{array}$ & $\begin{array}{c}\text { Relative } \\
\text { expanded } \\
\text { uncertainty } \\
U_{\mathrm{R}}\end{array}$ & Value & $\begin{array}{c}\text { Expanded } \\
\text { uncertainty } \\
U c_{\mathrm{i}}\left(k_{\mathrm{p}}=2\right)\end{array}$ & $\begin{array}{c}\text { Relative } \\
\text { expanded } \\
\text { uncertainty } \\
U_{\mathrm{R}}\end{array}$ \\
\hline 1 & 2 & 3 & 4 & 5 & 6 & 7 \\
\hline$c_{0}$ & 399.8637 & 20.80 & $5.2 \%$ & 389.3547 & 27.20 & $7.0 \%$ \\
\hline$c_{1}$ & 0.19303 & 0.01176 & $6.1 \%$ & 0.19842 & 0.01614 & $8.1 \%$ \\
\hline$c_{2}$ & 0.11233 & 0.01202 & $10.7 \%$ & 0.10852 & 0.01650 & $15.2 \%$ \\
\hline$c_{3}$ & 0.07003 & 0.01176 & $16.8 \%$ & 0.07617 & 0.01614 & $21.2 \%$ \\
\hline$c_{4}$ & -0.01537 & 0.00742 & $48.3 \%$ & -0.01997 & 0.01018 & $51.0 \%$ \\
\hline
\end{tabular}

\section{Discussion}

By applying the proposed approach we have calculated the measurement uncertainties of the mathematical model exponents/coefficients, which can be considered as the final result of the experimental research. It presents a different approach of considering the measurement uncertainty regarding the presented measurement uncertainty of single measurement. There is a huge difference between the relative expanded uncertainties and the exponents of one experimental plan as showed in column 4 . While for single measurement the relative expanded uncertainty was lower than $10 \%$, in this case the relative expanded uncertainty can vary between 5 and $50 \%$. This is a result of different propagation models generated from the regression matrices and it is showed that the measurement uncertainty of the single measurements influences differently on the mathematical model coefficients. Now, if we compare the results of the different experimental plans, column 4 and column 7 in table II, between full factorial plan and half replica, we can notice that there is a difference between the plans as a consequence of the different regression propagation models between the plans.

It is important to note that the high relative expanded uncertainty of the coefficients of the mathematical model results in significantly higher confidence boundaries of the calculated response surface compared to the confidence interval that can be presented within the DOE methodology or while analyzing the measurement uncertainty of single measurement. This is a significant explanation towards the differences in results between laboratories, and we consider these results as a contribution to expressing the real empirical model reliability. Moreover, this is the essential information which should be added to the mathematical models of the SMS, which should be able to use them in a proper way with real estimation of their possibility in the process of the optimization of the cutting process.

\section{Conclusion}

As a result of this work we can highlight that presenting the error in the experimental research in the machining process should be done by a comprehensive approach as presented in this paper so that the experimental research results would be proposed for use in the featured SMS and so that we would have a common base for interoperability between different laboratories. As a comprehensive approach, presenting the error of the experimental research not only of the single measurement but also of all the experimental investigation by calculating the measurement uncertainty of the mathematical model exponents/coefficients can be considered. These measurement uncertainties must include the uncertainty that arises from the cutting process itself beside the uncertainty of the measuring system.

The presented very high relative expanded uncertainty gives the real picture of the empirical modeling, and properly raises the question about the reliability of the calculated exponents. Having the detailed budget of measurement uncertainty gained by the proposed approach allows to discover the sources of errors and can guide the researchers to lowering the contributions. Although this approach is not simple to apply, it is highly recommended to implement it as usual practice in the experimental research. As a final recommendation we can propose that experimental and measurement practice can be considered good if the single measurement relative expanded uncertainties are below $5 \%$ with the intention to fit model exponents with reliable uncertainty.

\section{REFERENCES}

1. Arrazola P.J., Özel T., Umbrello D., Davies M., Jawahir I.S. „Recent advances in modelling of metal machining processes”. CIRP Annals Manufacturing Technology. 62, 2 (2013): p. 695-718.

2. Atluru S., Huang S.H., Snyder J.P. „A smart machine supervisory system framework". The International Journal of Advanced Manufacturing Technology. 58, 5-8 (2012): p. 563-572.

3. Deshayes L., Welsch L., Donmez A., Ivester R., Gilsinn D., Rhorer R. Whitenton E., Potra F. „Smart machining systems: issues and research trends". D. Brissaud, S. Tichkiewitch, P. Zwolinski (eds.). In Innovation in Life Cycle Engineering and Sustainable Development. Springer, Dordrecht (2006).

4. Min X. „Smart Machining System Platform for CNC Milling with the Integration of a Power Sensor and Cutting Model". Doctoral dissertation. University of New Hampshire, Durham (2007).

5. Schmitz T.L., Karandikar J., Kim Nam H., Abbas A. „Uncertainty in machining: Workshop summary and contributions". Journal of Manufacturing Science and Engineering. 133, 5 (2011): 051009-9.

6. Trajčevski N., Tomov M., Kuzinovski M., Cichosz P. „Introducing of measurement uncertainty in empirical power models of physical phenomena during machining processes". Mechanik. 88, 8-9 CD2 (2015): p. 55-62.

7. Trajčevski N. „Development of methodology to assess the quality of experimental results during research of physical phenomena in the process of machining by material removal". PhD thesis. University Ss. Cyril and Methodius. Skopje, Macedonia (2013). 